\title{
Technical Progress Report (11th Semi-Annual)
}

\author{
Semi-Annual Report \\ October 1, 1997 - March 31, 1998
}

Work Performed Under Contract No.: DE-FC21-92MC28178

For

U.S. Department of Energy

Office of Fossil Energy

Federal Energy Technology Center

P.O. Box 880

Morgantown, West Virginia 26507-0880

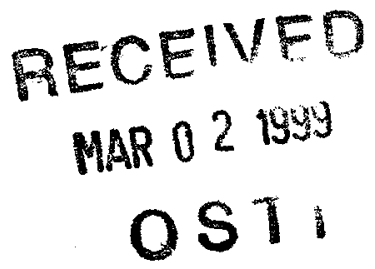

By

Institute of Gas Technology

1700 South Mount Prospect Road

Des Plaines, Illinois 60018-1804 


\section{Disclaimer}

This report was prepared as an account of work sponsored by an agency of the United States Government. Neither the United States Government nor any agency thereof, nor any of their employees, makes any warranty, express or implied, or assumes any legal liability or responsibility for the accuracy, completeness, or usefulness of any information, apparatus, product, or process disclosed, or represents that its use would not infringe privately owed rights. Reference herein to any specific commercial product, process, or service by trade name, trademark, manufacturer, or otherwise does not necessarily constitute or imply its endorsement, recommendation, or favoring by the United States Government or any agency thereof. The views and opinions of authors expressed herein do not necessarily state or reflect those of the United States Government or any agency thereof. 


\section{DISCLAIMER}

Portions of this document may be illegible in electronic image products. Images are produced from the best available original document. 


\author{
Technical Progress Report (11 th Semi-Annual) \\ Cooperative Agreement No. DE-FC21-92MC28178 \\ Reporting period: 10/1/97-03/31/98
}

\title{
PROJECT OBJECTIVE
}

The objective of this proposed program is to ensure reliable supply of high-quality natural gas by reducing the cost of treating subquality natural gas containing $\mathrm{H} 2 \mathrm{O}, \mathrm{CO} 2, \mathrm{H} 2 \mathrm{~S}$ and/or trace quantities of other gaseous impurities by applying high-efficiency contactors with structured packing using physical solvent $\mathrm{N}$-Formyl Morpholine and morpholine additives.

\section{EXECUTIVE SUMMARY}

A new physical solvent process has been developed for subquality gas upgrading. Morphysorb ${ }^{\circledR}$ technology utilizes a mixture of the physical solvent N-Formyl morpholine (NFM) and morpholine additive $\mathrm{N}$-acetyl morpholine (NAM) to remove $\mathrm{H}_{2} \mathrm{~S}$ and $\mathrm{CO}_{2}$ from subquality natural gas with minimal removal of valuable hydrocarbons. The high performance of Morphysorb ${ }^{\circledR}$ technology reduces producers operating costs up to $60 \%$ over the existing state-of-the-art physical solvent technologies or in lieu of operating cost savings, increases the plant capacity up to $30 \%$.

Further investigations have been carried out at the Shell Fandango plant in Texas with

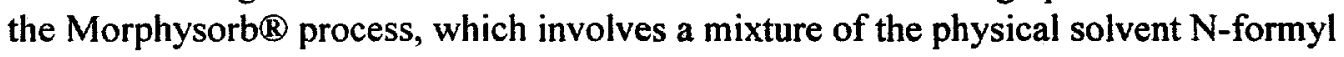
morpholine (NFM) and morpholine additive $\mathrm{N}$-acetyl morpholine (NAM), for upgrading of subquality natural gas.

The Morphysorb® process for treating subquality natural gas has numerous advantages including the following:

- $\quad \mathrm{High} \mathrm{H}_{2} \mathrm{~S} / \mathrm{CO}_{2}$ Loading - Resulting in lower solvent circulation; no refrigeration.

- Selectivity for $\mathrm{H}_{2} \mathrm{~S}$ - acid gas suitable for Claus sulfur recovery or sulfuric acid production.

- Low Capital Investment - Smaller equipment; carbon steel construction.

- Higher Product Yield - Less loss of $\mathrm{C}_{1}-\mathrm{C}_{6}$ hydrocarbons; higher Btu recovery.

- Chemically and Thermally Stable Solvent - Low solvent losses with low unit cost; safe and non-toxic.

Institute of Gas Technology
Washington Operations

1116 E Street, S.E.

Washington, DC 20003

(202) $547-7288$

(202) $547-1454$ FAX 
- Environmentally Compatible - Low emissions; biologically degradable; no hazardous emissions.

- Simultaneous Dehydration - separate dehydration facilities not necessary.

- Low Operating Costs - due to lower solvent circulation rate and lower gas recycle flow.

The economic evaluation of the Morphysorb $\otimes$ process field data indicated a savings minimum of $40 \%$ in operating costs and $20 \%$ in capital costs for upgrading subquality natural gas using Morphysorb ${ }^{\circledR}$ process compared to existing state-of-the-art commercial technologies. A total of $100+$ field experiments on a slip-stream of sour gas containing 15 - 45 mole \% $\mathrm{CO}_{2}$ from Shell's Fandango plant in south Texas confirmed that the Morphysorb® process is superior to existing state-of-the-art physical solvent technologies. The Morphysorb® process can be applied to both new and retrofit applications.

\section{WORK TO BE PERFORMED IN THIS REPORTING PERIOD}

- Construction of concrete pad for the chillers

- Placement of purchase order for procurement of chiller units

- $\quad$ Prepare mixed solvent field test plan and schedule.

- New piping connections for the chillers

- Insulate the contactor and liquid lines handling low temperature solvent

- Upgrade existing data acquisition system

- Installation of chillers

- Pilot plant preparation and Shakedown

- Initiation of field experiments

- Completion of field experiments 
Task 1. National Environmental Policy Act

This task was completed.

\section{Task 2. Field Experimental Site Selection}

This task was completed. Shell Fandango plant site was selected to continue the field tests using high sour gas composition and mixed morpholines. At the site, IGT has access to use sour gas with composition varying from 2 to 45 mole percent. IGT has installed a in-line gas mixer (unit supplied by Koch Engineering) which is capable of producing gas blends of desired composition.

\section{Task 3. Field Experimental Skid Unit Design And Preliminary Economic Evaluations}

To accommodate the use of mixed morpholines, a new chiller system has been designed. With the help of the new chiller system, the solvent temperatures can be maintained as low as $10^{\circ} \mathrm{F}$ in the contactor. The advantages of mixed morpholines in gas treating are increased acid loading, reduced circulation rate, lower methane absorption and substantial savings in operating costs compared to existing state-of-the-art physical solvent technologies.

\section{Task 4. Project Review}

This task was inactive.

Task 5. Information Required for NEPA, Field Site

This information required for NEPA for field test sites have been provided to DOE.

Task 6. Fluid Dynamic Studies 
This task was completed. The final topical report on the fluid dynamic studies on the plastic rotary contactor was prepared and presented to DOE and GRI.

\section{Task 7. Mass-Transfer Coefficient Studies}

This task was inactive.

\section{Task 8. Field Experimental Studies}

\section{FIELD TEST PLAN FOR NFM/NAM MIXED SOLVENT AT LOW TEMPERATURES:}

The objectives of field test program is to obtain field test data with following variables:

1. Variation of $\mathrm{CO}_{2}$ sour gas composition $(45,14,7$ mole\%)

2. Variation of absorber temperature (0 to $20 \mathrm{~F})$

3. Variation of absorber pressure (600-1000 psig)

4. Variation in reboiler load (no reboiler, hot flash and full operation of reboiler)

5. Variation of flash pressure (50-400 psig)

6. Simultaneous dehydration runs considering a hot flash

7. Few test runs with same conditions as Shell Fandango plant (same L/G ratio) to predict relative mixed solvent performance

8. Variation in solvent flow rates (3-12 gpm)

9. Exclusive Dehydration runs without chiller unit operation.

A field-test plan covering the above mentioned objectives is prepared in consultation with Krupp Uhde. The field test plan is given in the following table 1 :

TABLE 1. FIELD TEST PLAN

\begin{tabular}{|c|c|c|c|c|c|c|c|}
\hline Run \# & Pressure & $\begin{array}{c}\text { CO2 } \\
\text { mole\% }\end{array}$ & Temp. ${ }^{\circ} \mathrm{F}$ & $\begin{array}{c}\text { Gas Flow } \\
\text { Rate, } \\
\text { MSCF }\end{array}$ & $\begin{array}{c}\text { Solvent } \\
\text { Flow } \\
\text { Rate, }\end{array}$ & $\begin{array}{c}\text { Flash } \\
\text { Pressure } \\
, \text { psig }\end{array}$ & $\begin{array}{c}\text { Reboiler } \\
\text { Load \% }\end{array}$ \\
\hline
\end{tabular}




\begin{tabular}{|c|c|c|c|c|c|c|c|}
\hline & & & & & $\mathrm{gpm}$ & & \\
\hline 1 & 1000 & 45 & 0 & 50 & 12 & 65 & 0 \\
\hline 2 & 1000 & 45 & 0 & 100 & 12 & 100 & 0 \\
\hline 3 & 1000 & 45 & 0 & 250 & 12 & 300 & 0 \\
\hline $4^{*}$ & 1000 & 45 & 0 & 500 & 12 & 50 & 10 \\
\hline $5 *$ & 1000 & 45 & 0 & 800 & 12 & 100 & 10 \\
\hline 6 & 1000 & 45 & 20 & 50 & 12 & 65 & 80 \\
\hline 7 & 1000 & 45 & 20 & 100 & 12 & 65 & 70 \\
\hline 8 & 1000 & 45 & 20 & 200 & 12 & 65 & 60 \\
\hline $9^{*}$ & 1000 & 45 & 20 & 400 & 12 & 50 & 10 \\
\hline $10^{*}$ & 1000 & 45 & 20 & 800 & 12 & 50 & 10 \\
\hline 11 & 1000 & 14 & 20 & 50 & 12 & 65 & 100 \\
\hline 12 & 1000 & 14 & 20 & 100 & 12 & 65 & 90 \\
\hline $13^{*}$ & 1000 & 14 & 20 & 800 & 12 & 50 & 10 \\
\hline 14 & 1000 & 14 & 0 & 60 & 12 & 400 & 0 \\
\hline 15 & 1000 & 14 & 0 & 200 & 8 & 200 & 0 \\
\hline 16 & 1000 & 14 & 0 & 300 & 8 & 100 & 0 \\
\hline $17^{*}$ & 1000 & 14 & 0 & 700 & $\overline{8}$ & 65 & 10 \\
\hline $18^{*}$ & 1000 & 14 & 0 & 300 & 5 & 65 & 10 \\
\hline $19^{*}$ & 1000 & 14 & 0 & 600 & 5 & 65 & 10 \\
\hline $20^{*}$ & 1000 & 14 & 0 & 800 & 5 & 65 & 10 \\
\hline 21 & 1000 & 45 & 0 & 50 & 3 & 65 & 50 \\
\hline 22 & 1000 & 45 & 0 & 200 & 3 & 65 & 50 \\
\hline $23^{*}$ & 1000 & 45 & 0 & 400 & 3 & 65 & 10 \\
\hline 24 & 600 & 45 & 0 & 50 & 8 & 300 & 100 \\
\hline 25 & 600 & 45 & 0 & 100 & 8 & 200 & 100 \\
\hline 26 & 600 & 45 & 0 & 200 & 8 & 100 & 100 \\
\hline $27^{*}$ & 600 & 45 & 0 & 400 & 8 & 65 & 10 \\
\hline $28^{*}$ & 600 & 45 & 0 & 800 & 8 & 65 & 10 \\
\hline 29 & 1000 & 7 & 20 & 50 & 12 & 65 & 100 \\
\hline 30 & 1000 & 7 & 20 & 100 & 12 & 65 & 90 \\
\hline $31^{*}$ & 1000 & 7 & 20 & 800 & 12 & 50 & 10 \\
\hline 32 & 1000 & 7 & 0 & 60 & 12 & 400 & 0 \\
\hline 33 & 1000 & 7 & 0 & 200 & 8 & 200 & 0 \\
\hline 34 & 1000 & 7 & 0 & 300 & 8 & 100 & 0 \\
\hline 35 & 1000 & 7 & 0 & 700 & 8 & 65 & 10 \\
\hline $36^{*}$ & 1000 & 7 & 0 & 300 & 5 & 65 & 10 \\
\hline 37 & 1000 & 7 & 0 & 600 & 5 & 65 & 10 \\
\hline $38^{*}$ & 1000 & 7 & 0 & 800 & 5 & 65 & 10 \\
\hline
\end{tabular}


Please note the regenerator pressure will be maintained at 5 psig or lower for all the above experiments. In addition to the above, an additional three exclusive dehydration experiments need to be conducted to evaluate the performance of mixed solvent using $14 \% \mathrm{CO}_{2}$ sour gas.

\begin{tabular}{|c|c|c|c|c|c|c|c|}
\hline Run \# & Pressure & $\begin{array}{c}\text { CO2 } \\
\text { mole\% }\end{array}$ & Temp. ${ }^{\circ} \mathrm{F}$ & $\begin{array}{c}\text { Gas Flow } \\
\text { Rate, } \\
\text { MSCF }\end{array}$ & $\begin{array}{c}\text { Solvent } \\
\text { Flow } \\
\text { Rate, } \\
\text { gpm }\end{array}$ & $\begin{array}{c}\text { Flash } \\
\text { Pressure, } \\
\text { psig }\end{array}$ & $\begin{array}{c}\text { Reboiler } \\
\text { Load \% }\end{array}$ \\
\hline 39 & 1000 & 14 & 90 & 300 & 12 & 50 & 10 \\
\hline 40 & 1000 & 14 & 90 & 500 & 12 & 100 & 10 \\
\hline 41 & 1000 & 14 & 90 & 800 & 12 & 200 & 10 \\
\hline 42 & 1000 & 14 & 90 & 800 & 12 & 100 & 10 \\
\hline
\end{tabular}

Field-tests with N-Formyl Morpholine and Morpholine Additive solvent mixture:

In conjunction with proposed field tests with mixed solvent system (figure 1), the following jobs and/or modifications were made during last few weeks:

- Chiller/Refrigeration Unit: A chiller system has been ordered on Chiller Manufacturing company. The chiller units shall be supplied by end of December' 97 . The Chiller manufacturing company field engineer will be at site during installation. The chillers will be installed during $2^{\text {nd }}$ week January' 98 at Shell's Fandango plant location in south Texas. The chiller units are capable of the chilling the solvent to $-4^{\circ} \mathrm{F}$ in the contactor with a maximum flow rate $12 \mathrm{gpm}$.

- Contactor and all piping handling low solvent temperature solvent need has been insulated using 3inch thick polyurethane material.

- All instruments should be checked for low temperature measurements, if required need to be replaced.

- Upgraded the existing data acquisition system to accommodate newly added process equipment and their instruments. 


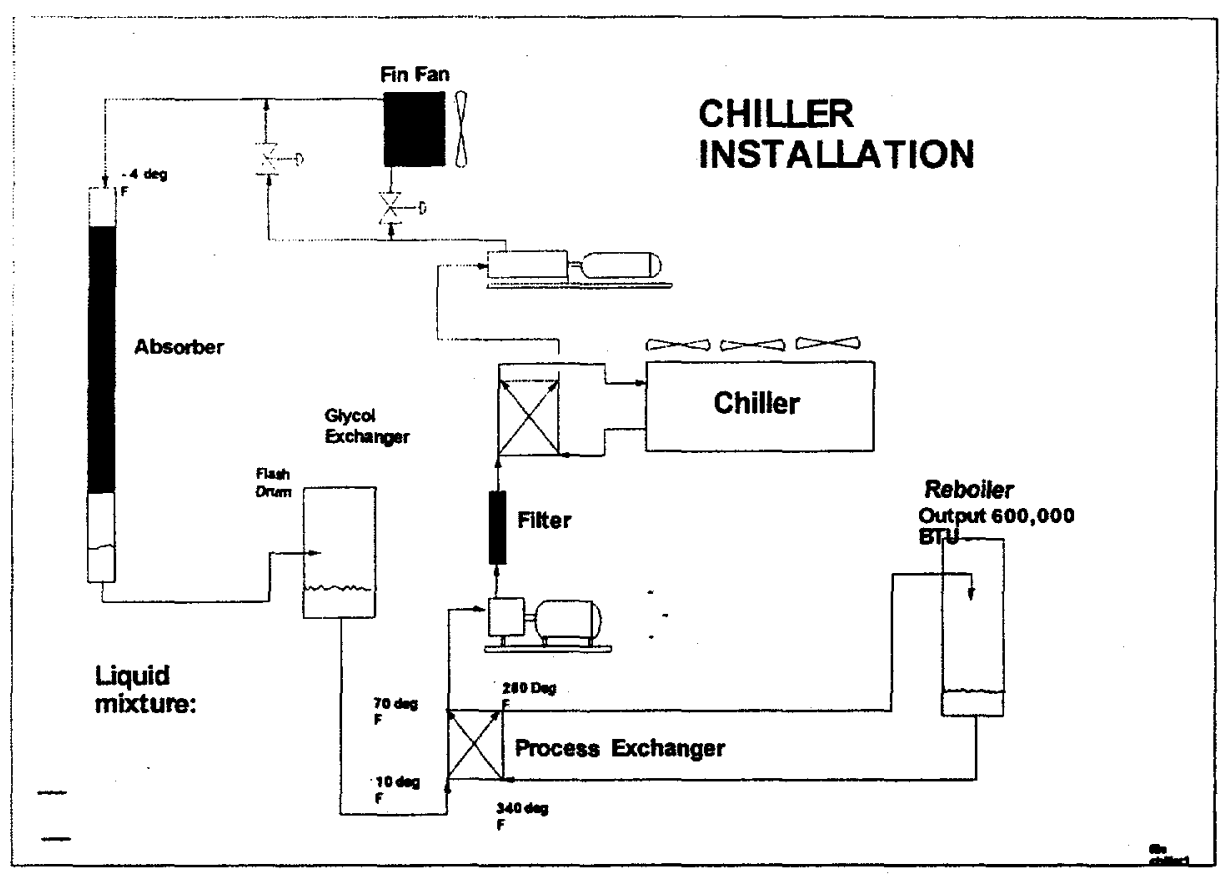

Figure 2. Process flow diagram of the field test unit with chiller unit

During the month of February'98, a total of 27 field experiments have been successfully completed using Morphysorb process. During the field tests a sour gas composition varied from 7 to 45 mole percent to collect data for modeling.

Task 9. Data Analysis and Reports

A paper on this project was presented at Gas processors Association (GPA) annual meeting held at Dallas during March 16-18, 1998. A copy of the paper is attached in Appendix A of this report. A paper on this project is also accepted for oral presentation at International Gas Research Conference (IGRC) to be held in November'98 in San Diego.

A detailed analysis of field tests conducted in February shall be submitted in detail in the next semiannual report. 


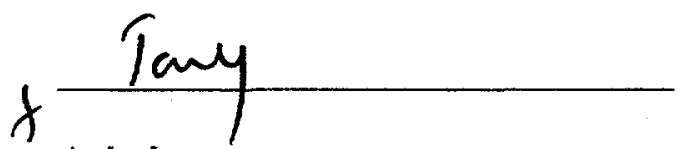

A. L. Lee

Managing Director

Gas Processing and

Catalyst Research

847/768-0572

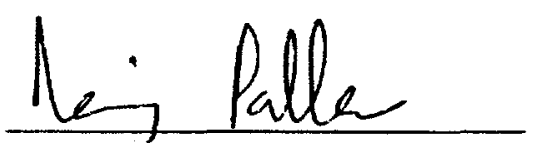

Raj Palla

Manager

Gas Processing Research

847/768-0535

This report was prepared by Institute of Gas Technology pursuant to U.S. Department of Energy - Agreement No. DE-FC21-92MC27391 and the Gas Research Institute Contract No. 5092-2222459. However, neither IGT, the Department of Energy, nor GRI, nor any person acting on behalf of any of them.

a. Makes any warranty or representation, expressed or implied, with respect to the accuracy, completeness, or usefulness of the information contained in this report, or that the use of any information, apparatus, method, or process disclosed in this report may not infringe privately-owned rights, or

b. Assumes any liability with respect to the use of, or for damages resulting from the use of, any information, apparatus, method, or process disclosed in this report.

Reference to trade names or specific commercial products, commodities, or services in this report does not represent or constitute an endorsement, recommendation, or opinion of suitability by GRI or IGT of the specific commercial product, commodity, or service.

This is an interim report; hence, the data, conclusions, and calculations are preliminary and should not be construed as final. 
- Technical Progress Report Page 9
October 25, 1998

IGT Project No. 61103

APPENDIX A

A copy of the paper presented at GPA's $7^{\text {th }}$

Annual Meeting in March' 98 


\title{
ADVANCEMENTS IN TREATING SUBQUALITYNATURAL GAS USING N-FORMYL MORPHOLINE
}

\author{
Nagaraju Palla and Anthony L. Lee \\ Institute of Gas Technology \\ Dr. Manfred Gross, H. Max Hooper, and Johannes Menzel \\ Krupp Uhde GmbH \\ Dennis Leppin \\ Gas Research Institute
}

\begin{abstract}
Process selection for gas treating is a complex phenomenon because processing requirements vary widely, and there are many gas sweetening solvents that are available to meet the requisite specification. Over the past few years, the Institute of Gas Technology (IGT) and Krupp Uhde GmbH (KU) have been conducting research on a physical solvent N-Formyl Morpholine (NFM) for treatment of subquality natural gas because of its advantages of lower energy consumption, higher $\mathrm{CO}_{2} / \mathrm{H}_{2} \mathrm{~S}$ gas loadings, selective absorption of $\mathrm{CO}_{2} / \mathrm{H}_{2} \mathrm{~S}$, and lower loss of valuable $\mathrm{Cl}-\mathrm{C} 6$ hydrocarbons as compared with other commercial physical solvents. Field experiment studies from the 1 MMSCFD pilot plant unit operating at Shell's Fandango facility confirms NFM as a cost-effective gas treating solvent. To date, a total of seventy-eight (78) tests using Koch's random, high capacity and high-efficiency structured packing have been completed. These field experiments were conducted at wellhead conditions at 1000 psig using slipstream from the Shell plant containing sour gas concentrations up to 43 mole percent $\mathrm{CO}_{2}$. The data, when used in a sophisticated process simulation, predict a minimum of $40 \%$ operating cost savings depending upon sour gas concentration. This paper explains the development of NFM technology with results from laboratory and field tests. This paper also discusses case studies pertaining to NFM application to retrofits, as well as new plants. Furthermore, this paper illustrates the scaling-up calculations from field test investigations. The potential of mixed solvent - NFM and morpholine additives - will also be discussed for increased acid gas loading, reduced circulation rate, and column size. This emerging technology is the product of extensive research by IGT and is commercially available through $\mathrm{KU}$ for gas treating applications.
\end{abstract}

\section{INTRODUCTION}

When sour gas stream consists of significant portion of acid gases, the cost of treating them by heat regenarable solvents may be out of proportion to the value of the sales gas. This phenomenon has made research engineers to develop a processes that utilizes nonreactive organic solvents for treating sour gas streams consisting of higher acid gas concentrations. These organic solvents physically absorb acid gases and regenerated by series of flashes by reducing pressure without any thermal regeneration. Each mole of $\mathrm{CO}_{2}$ reacts chemically with a mole of amine. This chemical bond requires heat to break it and liberate the $\mathrm{CO}_{2}$ in the regeneration step. Heat and inert stripping vapors are sometimes supplied to effect a more efficient regeneration. Most of these solvents show a greater solubility for $\mathrm{H}_{2} \mathrm{~S}$ than $\mathrm{CO}_{2}$, and they dissolve other organic sulfur compounds to varying degrees. Economical removal of bulk quantities of acid gases is the main advantage. Approximately $30 \%$ of proven reserves fall into this subquality natural gas category according to studies conducted by GRI ${ }^{1,2}$. 
$\mathrm{N}$-Formyl morpholine (NFM) is evaluated for treatment of subquality natural gas because of its potential advantages of reduced refrigeration, higher capacity for $\mathrm{H}_{2} \mathrm{~S}$ and $\mathrm{CO}_{2}$, less loss of valuable hydrocarbons, and lower operating costs compared with other commercial physical solvents. An experimental program to obtain data for evaluating NFM's gas conditioning and dehydration potential has included the following:

- Thermodynamic Properties: vapor-liquid equilibrium, auto-refrigeration, and density

- Transport Properties: viscosity, surface tension, diffusion coefficients, and volumetric mass transfer coefficients.

- Chemical Properties: thermal stability and corrosion

- Field experiments

\section{Criteria for selection of the solvent}

The criteria for selection of particular kind of solvent for gas treating applications should include performance specifications, solvent absorption characteristics, energy requirements and commercial applications. Extensive VLE experimental data, field test evaluations and computer simulations indicate that NFM has excellent solvent characteristics, which are as follows:

\section{Performance Specifications:}

(a) High product gas quality

(b) Maximum product methane and $\mathrm{CO}_{2}$ recovery

(c) Product gas meeting pipeline specifications

(d) Meeting environmental regulations

(e) High Btu sales gas

(f) High capacity for $\mathrm{H}_{2} \mathrm{~S}$ and $\mathrm{CO}_{2}$ removal

(g) Simultaneous dehydration capacity

(h) Lower solvent re-circulation rates

\section{Solvent Absorption Characteristics:}

(a) High acid-gas loading capacity

(b) Used efficiently in either bulk or selective acid-gas removal processes

(c) Facilitating the conversion of $\mathrm{COS}$ to $\mathrm{H}_{2} \mathrm{~S}$ and thereby assist in the conversion of sulfur compounds to elemental sulfur as is a typical component tail-gas treatment process.

(d) Lower hydrocarbon absorption

(e) $\mathrm{H}_{2} \mathrm{~S} / \mathrm{CO}_{2}$ Selectivity, or the ability of the solvent to remove undesirable components $\left(\mathrm{CO}_{2}, \mathrm{CO}, \mathrm{H}_{2} \mathrm{~S}, \mathrm{COS}\right.$, etc.), while leaving the desirable components $\left(\mathrm{CH}_{4}, \mathrm{C}_{2} \mathrm{H}_{6}, \mathrm{C}_{3} \mathrm{H}_{8}\right.$, etc.)

\section{Energy Requirements:}

(a) Little or no refrigeration is required

(b) Energy requirements are substantially lower, hence lower operating costs.

\section{Solvent considerations:}

(a) Low vapor pressure - less solvent loss

(b) Chemically and thermally stable 
(c) Regenerates easily with minimum energy requirement

(d) Bio-degradable, no toxicity or environmental problems

(e) NFM with high boiling point is stable at maximum operating temperature of $200^{\circ} \mathrm{C}$, significantly below the $243^{\circ} \mathrm{C}$ boiling point.

\section{DEVELOPMENT OF NFM PROCESS}

The Institute of Gas Technology (IGT) has been working on gas processing technology in cooperation with Krupp Uhde $\mathrm{GmbH}(\mathrm{KU})$, that will reduce gas processing costs for current production and allow subquality gas to be economically produced that would have been otherwise, not produced. The experimental program being discussed in this paper has been in progress since 1990. It has primarily focused on the evaluation of N-Formyl Morpholine (NFM), shown in Figure 1, as a physical solvent for the cost-effective upgrading of subquality natural gas to pipeline quality. The selection of NFM for this program was based on previous work conducted by IGT in the selective removal of hydrogen sulfide, and carbon dioxide from coal gasifier effluents ${ }^{3}$. That work showed that the use of NFM resulted in a significant cost advantage over 107 other solvents for that application.

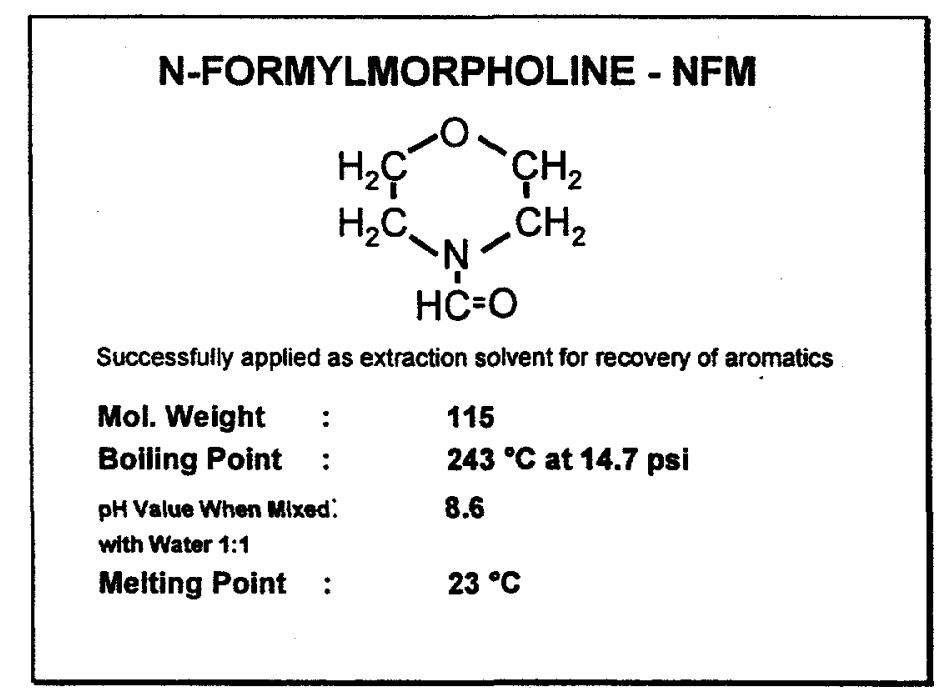

Figure 1. Properties of N-Formyl Morpholine

The project approach for the development of this NFM process has been divided into the following main categories:

Phase I: $\quad$ Obtain vapor-liquid equilibrium, physical properties and additional published literature data

Phase II: $\quad$ Obtain mass-transfer coefficients using 2-inch absorber/stripper apparatus. Calculate equation-of-state parameters and binary interaction parameters using VLE data

Phase III: Develop a gas processing model using Aspen Plus simulation program and evaluate economic advantages of the NFM process compared to commercial physical solvent

Phase IV: $\quad$ Design a pilot plant, skid-mounted field test unit and conduct field test experiments

Phase V: $\quad$ Commercialization of NFM related technologies 


\section{MAJOR ACCOMPLISHMENTS}

\section{Vapor-Liquid Equilibrium (VLE) Experiments}

The Vapor-Liquid Equilibrium apparatus developed at IGT is capable of handling all sulfur species and operating from 25 to $3000 \mathrm{psia}$ at temperatures from $60^{\circ}$ to $300^{\circ} \mathrm{F}$. This apparatus consists of a 1-liter vessel in which vapor and liquid phases are continuously circulated. On-line phase sampling is conducted at system pressure and temperature. Small sample volumes ( 1 microliter samples for liquid and 1 milliliter for gases) are withdrawn to ensure minimal disturbance of the system composition. Over 1000 data points have been collected for mixtures of NFM and water over the following ranges of conditions:

Temperature, ${ }^{\circ} \mathrm{F}: \quad 60-300$

Pressure, psia: $\quad 25-1150$

Gas Compositions:

$$
\begin{array}{ll}
\text { Single Component } & \mathrm{CO}_{2}, \mathrm{H}_{2} \mathrm{~S}, \mathrm{COS}, \mathrm{C}_{3} \mathrm{H}_{8} \text {, and } \mathrm{C}_{4} \mathrm{H}_{10} \\
\text { Mixtures } & \mathrm{CH}_{4}, \mathrm{CO}_{2}, \mathrm{H}_{2} \mathrm{~S}, \mathrm{C}_{2} \mathrm{H}_{6}, \mathrm{C}_{3} \mathrm{H}_{8}, \mathrm{C}_{4} \mathrm{H}_{10}, \\
& \mathrm{C}_{4} \mathrm{H}_{12}, \text { and } \mathrm{C}_{6} \mathrm{H}_{14}
\end{array}
$$

The data collected indicate the following solubility ranking by $\mathrm{K}$-values (mole fraction of component " $A$ " in the gas phase divided by the mole fraction of that component in the liquid phase at equilibrium) at $6891 \mathrm{kPa}(1000$ psia), 289 to $322 \mathrm{~K}\left(60^{\circ}\right.$ to $\left.120^{\circ} \mathrm{F}\right)$, and for the compositions tested:

$\mathrm{CH}_{4}<\mathrm{C}_{2} \mathrm{H}_{6}<\mathrm{C}_{3} \mathrm{H}_{8}<\mathrm{n}-\mathrm{C}_{4} \mathrm{H}_{10}<\mathrm{i}-\mathrm{CH}_{10}<\mathrm{CO}_{2}<\mathrm{C}_{5} \mathrm{H}_{12}<\mathrm{H}_{2} \mathrm{~S}<\mathrm{C}_{6} \mathrm{H}_{14}$

This ranking indicates a potential for using NFM in selective processes. For example, in relative terms the solubility of $\mathrm{H}_{2} \mathrm{~S}$ is roughly three times greater than $\mathrm{CO}_{2}$ at the conditions tested.

\section{Computer modeling and economic evaluations}

ASPENTM Plus process simulation software package was used to regress VLE and other data to obtain the appropriate equation-of-state coefficients. Peng-Robinson, Redlich-Kwong-Soave, Redlich-Kwong-ASPEN'M, and Redlich-Kwong-UNIFAC thermodynamic models were investigated. The model that was able to give the best fit to the data over the relevant range was Peng-Robinson, which modified it with binary interaction coefficients. These coefficients were fitted from the data collected using the maximum likelihood principle to formulate the objective function, and then minimizing that function by the algorithms of Deming and Britt and Lueke. In order to estimate the performance of NFM as a solvent system, a model of a gas processing plant was created using ASPEN'M Plus Process simulation package and evaluated NFM solvent performance compared to commercial physical solvent ${ }^{4}$. Based on the VLE data, NFM process effectiveness was evaluated using sour gas streams with low, medium and high total acid gas concentrations. The simulation results indicate that NFM solvent system will significantly outperform the commercial physical solvent applications for gas sweetening processes. In addition to economic evaluations of NFM solvent by IGT, an independent study conducted by Krupp Uhde GmbH (IGT's commercial partner for development NFM Process for gas treating applications) also confirms IGT's findings as indicated in Table 1 below. 
Table 1. NFM OPERATING COST SAVINGS

\begin{tabular}{|c|c|c|c|}
\hline & Acid Gas Content (mol \%) & IGT Study & KU Study \\
\hline Case A & $\mathrm{CO}_{2} 6.3 \%, \mathrm{H}_{2} \mathrm{~S} 2.7 \%$ & $40 \%$ & $29 \%$ \\
\hline Case B & $\mathrm{CO}_{2} 35.0 \%, \mathrm{H}_{2} \mathrm{~S} 2.0 \%$ & $53 \%$ & $51 \%$ \\
\hline Case C & $\mathrm{CO}_{2} \quad 11.4 \%, \mathrm{H}_{2} \mathrm{~S} 7.9 \%$ & $\cdots$ & $31 \%$ \\
\hline
\end{tabular}

\section{PILOT PLANT TESTING}

With the magnitude of potential savings estimated, as indicated in Table 1, the sponsors of this research program - Gas Research Institute (GRI), Department of Energy (DOE), the cofunding partners of the IGT Sustaining Membership Program (SMP), Krupp Uhde GmbH and its industrial partners, Huntsman Chemical Company, and Shell Western Exploration and Production Corporation (SWEPI) - embarked on a field test program to confirm the earlier predictions which were based on laboratory bench-scale apparatus. For the purpose of field testing at the gas wellhead site, a 10-gpm skid-mounted pilot plant was designed and constructed to test both physical and chemical solvents. The skid field unit as shown Figure 2, is equipped with a nominal 8-inch-diameter absorption column. The unit will have a gas processing capacity ranging from 0.25 to 1.00 million SCF/d depending on the acid gas content of the feed gas. The field-testing was carried at SWEPI's Fandango plant site located in south Texas for a period of 12 months. The operating parameters of field tests using random and structured packing are indicated in the Table 2.

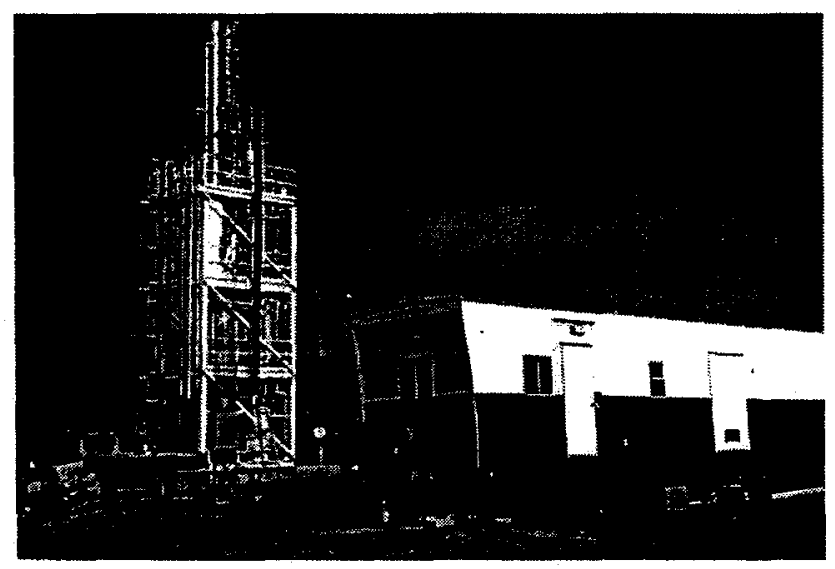

Figure 2. SKID-MOUNTED PILOT PLANT TEST UNIT 
Table 2. OPERATING PARAMETERS FOR FIELD TESTS

\begin{tabular}{|l|l|}
\hline PARAMETER & RANGE \\
\hline Contactor Pressure, $\mathrm{psig}$ & $500-1000$ \\
\hline Contactor Temperature, $^{\circ} \mathrm{F}$ & $85-115$ \\
\hline Flash Tank Pressure, $\mathrm{psig}$ & $65-400$ \\
\hline Feed Gas Flow Rate, MSCF/d & $200-800$ \\
\hline NFM Solvent Circulation rate, gpm & $5-12$ \\
\hline Reboiler Temperature, ${ }^{\circ} \mathrm{F}$ & 330 \\
\hline
\end{tabular}

The process flow scheme for IGT's pilot plant is very similar to that of the conventional amine treating systems. The sour feed gas is contacted countercurrently with lean NFM solution in an 8-inch-OD absorber filled with random or structured packing with a single, top solvent entry point. Normally, the absorber pressure is maintained at $1000 \mathrm{psig}$; however, for the purpose of obtaining data at various partial pressures of $\mathrm{CO}_{2}$, absorber pressure is varied. Five operational variables were studied: inlet sour gas flow rate, NFM solvent circulation tare, lean solvent temperature, reboiler temperature (NFM stripping rate), and flash tank pressure. The following five cases were studied using Shell's slipstream at Fandango plant facilities in south Texas.

1. $\mathrm{CO}_{2}$ absorption performance tests at fixed circulation rate with varying feed gas flow rates

2. Reboiler tests to test regeneration quality of the NFM solvent with varying reflux ratio

3. Tests to verify the effects of partial pressure of $\mathrm{CO}_{2}$ on absorption

4. Tests at varying circulation rates to verify hydraulic performance

5. Reruns to check repeatability and reliability of the experimental data.

Pilot plant data were obtained from four gas streams: inlet sour gas, sweet gas, flash drum overhead gas, and acid gas from stripper reflux accumulator; and three liquid streams: high-pressure rich NFM solvent with dissolved gases from contactor, rich NFM solvent from the flash tank, and lean NFM feed to the contactor. 


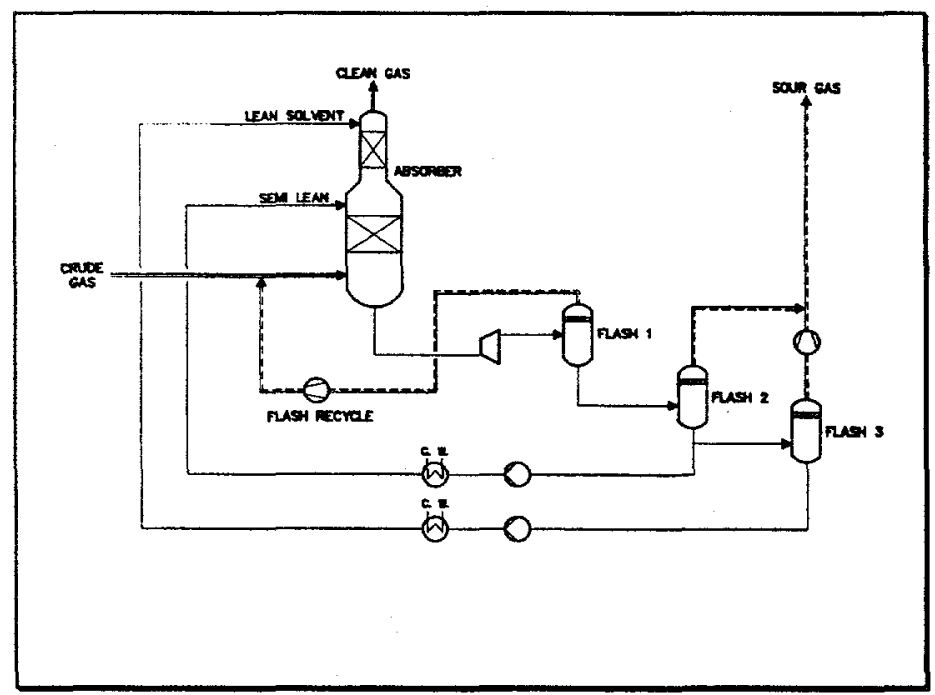

Figure 3. Upgrading Subquality Natural Gas to Pipeline Specification

After successful completion of pilot plant field experiments, supplemented by VLE data and Krupp Uhde's experience with NFM solvent, some process applications have been developed using Aspen Plus ${ }^{\mathrm{TM}}$ simulation package to estimate the NFM solvent performance compared with other physical solvents processes which are commercially available today. The Redlich-Kwong-Soave equation-of-the-state, thermodynamic model was used for calculation of gas phase behavior and Uniquac parameters for liquid phase. It is necessary to remove carbon dioxide, $\mathrm{CO}_{2}$, from the treated gas stream for a variety of reasons. If the gas is to be sold to the public, $\mathrm{CO}_{2}$ must be removed from the gas stream to maintain the heating value of the gas. The heating value of most natural gas streams is about 1000 Btu per 1000 SCF. To stay above the minimum heating value, the gas sold to the public usually contains no more than $2 \% \mathrm{CO}_{2}$. Figure 3 shows the process flow diagram for this case study chosen to evaluate NFM performance over other solvents.

As shown in the above diagram, the process consists of absorber with lean and semi-lean solvent stages, and three subsequent flash stages without any thermal generation of the solvent. The flash gas from the first flash stage is recycled back to the absorber to lower the methane loss. In the second stage, the semi-lean solvent is regenerated by flash reduction and then pumped back to the absorber. The third stage flash is a vacuum flash and the regenerated lean solvent is circulated to the top of the absorber. A summary of the comparison of performance of the NFM process and conventional solvent systems is given in the following table 3. 
Table 3. Comparison between NFM and a commercial physical solvent system

\begin{tabular}{|c|c|c|c|c|c|}
\hline $\begin{array}{l}\text { Feed Gas } \\
\text { Product Gas }\end{array}$ & $\begin{array}{l}\text { Flow, } \\
\text { MMSCFD } \\
80.90 \\
57.30\end{array}$ & $\begin{array}{l}\text { Pressure } \\
\text { Psig } \\
1015 \\
1000\end{array}$ & $\begin{array}{l}\mathrm{CO}_{2 .} \\
\mathrm{Vol} \% \\
30.0 \\
2.0\end{array}$ & $\begin{array}{l}\mathrm{H}_{2} \mathrm{~S} \\
\text { Ppmv } \\
20 \\
<4\end{array}$ & $\begin{array}{l}\mathrm{CH}_{4} \\
\mathrm{Vol} . \% \\
70.0 \\
98.0\end{array}$ \\
\hline \multicolumn{2}{|l|}{ Solvent } & \multicolumn{2}{|l|}{ NFM } & \multicolumn{2}{|c|}{ Conventional Solvent } \\
\hline \multicolumn{2}{|c|}{$\begin{array}{l}\text { Circulation rate. semi-lean, } \\
\text { gpm }\end{array}$} & 3302 & & & $\begin{array}{l}403 \\
321\end{array}$ \\
\hline Electrical energ & $y(M W)$ & \multicolumn{2}{|c|}{4.0} & \multicolumn{2}{|c|}{$\overline{8.6}$} \\
\hline
\end{tabular}

\section{APPLICATION OF MIXED MORPHOLINES (MORPHYSORB ${ }^{\circledR}$ PROCESS)}

In order to extend the range of application of the physical solvent NFM, further investigations have been carried out for upgrading of natural gas. These further investigations include particularly the usage of a solvent mixture of NFM and NAM (N-Acetylmorpholine).

\section{Solidification behaviour}

The solidification behaviour of NFM shows that pure NFM solidifies at a temperature of approximately $23^{\circ} \mathrm{C}\left(73^{\circ}\right.$ F). Small portions of water influence the solidification drastically, resulting in a solidification point of $7^{\circ} \mathrm{C}\left(45^{\circ} \mathrm{F}\right)$ at a water content of $5 \%$ (weight). Hence, the application of NFM containing a few percent of water is limited within an absorption temperature range above $10^{\circ} \mathrm{C}\left(50^{\circ} \mathrm{F}\right)$.

In contrast, a mixture of NFM and NAM is characterised by different solidification behaviour. 


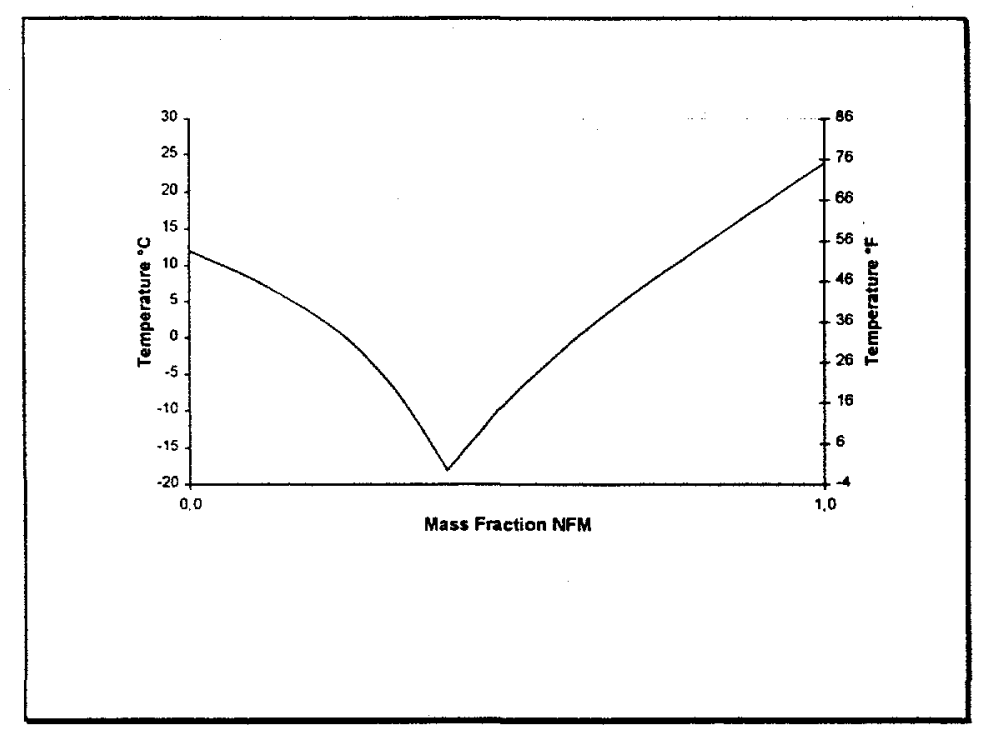

\section{Figure 4. SIMPLIFIED NFM/NAM SOLIDIFICATION DIAGRAM}

Figure 4 shows the solidification curves of mixtures of pure NFM and NAM. These experimental data correspond to the data calculated from the solidification enthalpies. Depending on the mass fraction of NFM and NAM the lowest solidification temperature is about $-17^{\circ} \mathrm{C}\left(1.5^{\circ} \mathrm{F}\right)$.

Taking these results into consideration, the Morphysor $b^{\circledR}$ process can now be compared to other physical solvents at temperatures down to $-10^{\circ} \mathrm{C}\left(14^{\circ} \mathrm{F}\right)$ and is applicable at these low temperatures.

The lab investigations of the solubility of several gaseous components, such as $\mathrm{CO}_{2}, \mathrm{H}_{2} \mathrm{~S}$ and $\mathrm{CH}_{4}$ in the Morphysorb solvent could be confirmed by pilot plant tests and show that both solvents - NFM and NFM/NAM mixtures - have practically the same solubility data at comparable temperatures. The pilot plant tests have been carried out at the Shell Oil's Fandango Site.

\section{Morphysorb® Process Configuration}

Krupp Uhde has studied several potential process arrangements to take advantage of the Morphysorb solvent. By way of example, three process arrangements are presented.

Bulk $\mathrm{CO}_{2}$ removal from natural gas 


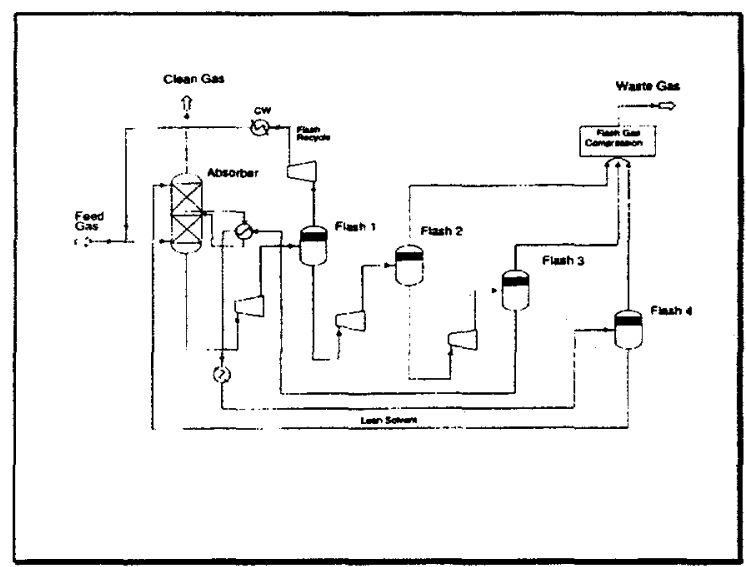

Figure 5. BULK $\mathrm{CO}_{2}$ REMOVAL

The equipment arrangement (Figure. 5) includes the absorber with only semi-lean stage contacting and interstage solvent cooling, plus four flash stages at different pressures for solvent regeneration. The first flash is performed at 537 psia for recycling of the flashed gas.

\begin{tabular}{|c|c|c|c|c|c|c|c|}
\hline & $\begin{array}{c}\text { Flow } \\
\text { (MMscfd) }\end{array}$ & $\begin{array}{l}\text { Pressure } \\
\text { (psi) }\end{array}$ & $\begin{array}{c}\text { Temp. } \\
\text { ('F) }\end{array}$ & 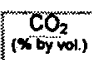 & $\begin{array}{c}\mathrm{H}_{2} \mathrm{~S} \\
\text { (x) by vol) }\end{array}$ & $\begin{array}{c}C P_{4} \\
\left.\text { ( } x^{\prime} \text { by vol. }\right)\end{array}$ & $\begin{array}{l}N_{2} \text { a. } \\
\text { (s). }\end{array}$ \\
\hline Feed Gas: & 2,100 & 1,014 & 65 & 710 & 0.5 & 28.0 & 0.5 \\
\hline Clean Gas: & 720 & 985 & 36 & 17.8 & 0.2 & 80.5 & 1.5 \\
\hline Waste Gas & 1,380 & & & 99.0 & 0.6 & 0.5 & \\
\hline
\end{tabular}

\begin{tabular}{|ll|r|}
\hline & & Morphysorb \\
\hline Solvent Circulation & GPM & $30,335.0$ \\
Electrical Energy & MW & 13.7 \\
Cooling Water & GPM & $2,860.0$ \\
$\mathrm{CH}_{4}$ loss & MMscfd & 7.1 \\
\hline Total utility costs & MMS/a & 14.5 \\
\hline Specific costs & cenUMscf CH & 7.1 \\
& in Clean Gas & \\
\hline
\end{tabular}

\section{Figure 6. UTILITY COSTS FOR BULK $\mathrm{CO}_{2}$ REMOVAL}

Figure 6 lists the nature of the task and the utility figures for $\mathrm{CO}_{2}$ removal from $71 \%$ to $17.8 \%$ vol. from natural gas using Morphysorb solvent. The feed gas flow is $2100 \mathrm{MMscfd}$ at $1014 \mathrm{psia}$ and $65^{\circ} \mathrm{F}$.

The entire nature of the task includes not only the $\mathrm{CO}_{2}$ absorption but also the required sales gas compression and waste gas compression up to a very high pressure for aquifer storage that are not considered in this evaluation. The utility figures will show the dimension of needed energy and costs, which can be expected for the $\mathrm{CO}_{2}$ removal of this huge gas flow with more than $70 \%$ of $\mathrm{CO}_{2}$. 


\section{$\mathrm{CO}_{2}$ removal from natural gas}

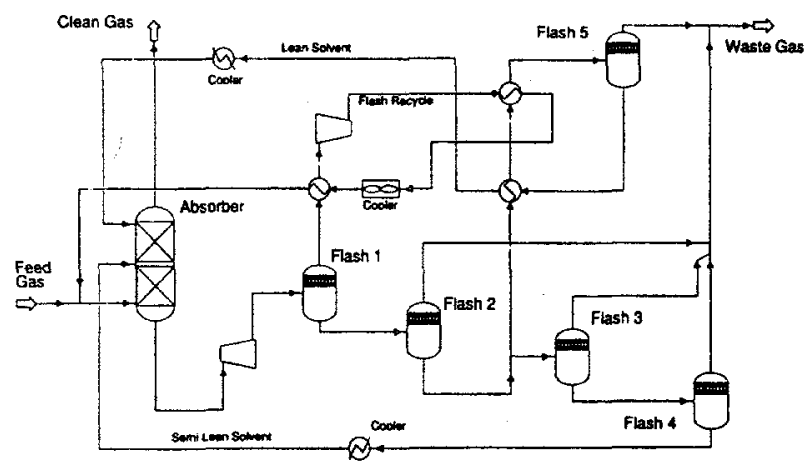

Figure 7. CO2 REMOVAL FROM 14\% TO PIPELINE SPEC.

Figure 7 shows the simplified process flow diagram. The equipment arrangement includes the absorber with lean and semi-lean stage contacting, plus five flash stages at different pressures for solvent regeneration. The first flash is performed at 200 psia for recycling of the flashed gas. $\mathrm{H}_{2} \mathrm{~S}$ will be removed down to few ppm.

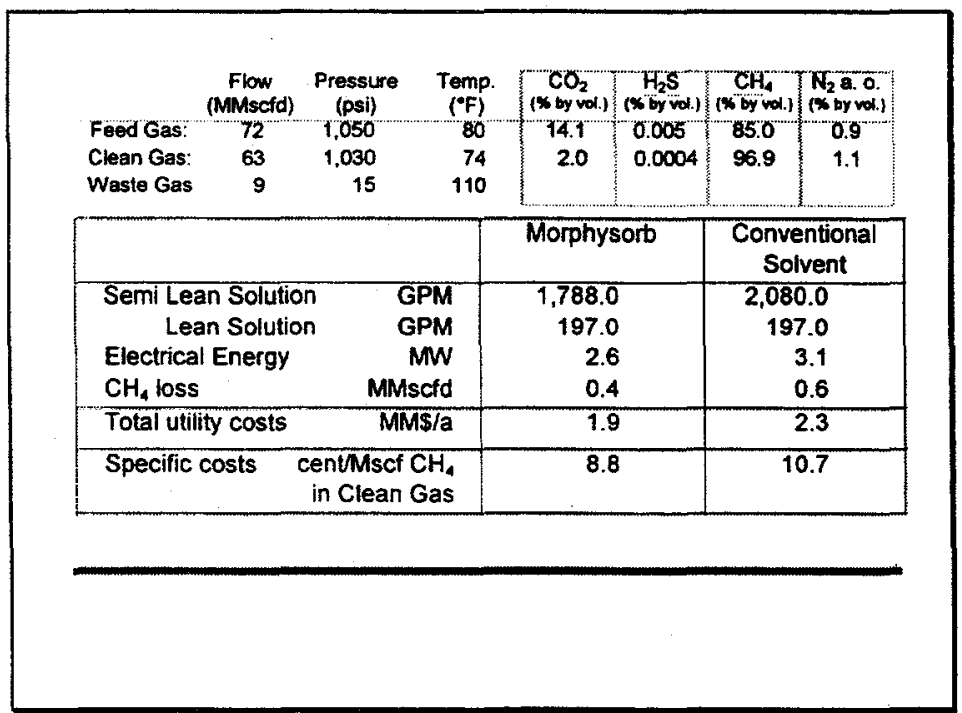

Figure 8. UTILITY COSTS - $\mathrm{CO}_{2}$ REMOVAL 
Figure 8 lists the nature of the task and the utility figures for $\mathrm{CO}_{2}$ removal from $14 \%$ to $2 \%$ vol. and compares the utility costs of Morphysorb with those of a conventional physical solvent. The feed gas flow is $72 \mathrm{MMscfd}$ at 1050 psia and $80^{\circ} \mathrm{F}$. Due to the advantageous properties of the Morphysorb solvent, such as high loadings of acid gases, low solubility of $\mathrm{CH}_{4}$ and, consequently low loss of $\mathrm{CH}_{4}$, the utility costs would be approximately $18 \%$ lower of those of a conventional physical solvent.

\section{Partial removal of $\mathrm{CO}_{2}$ and $\mathrm{H}_{2} \mathrm{~S}$ from natural gas}

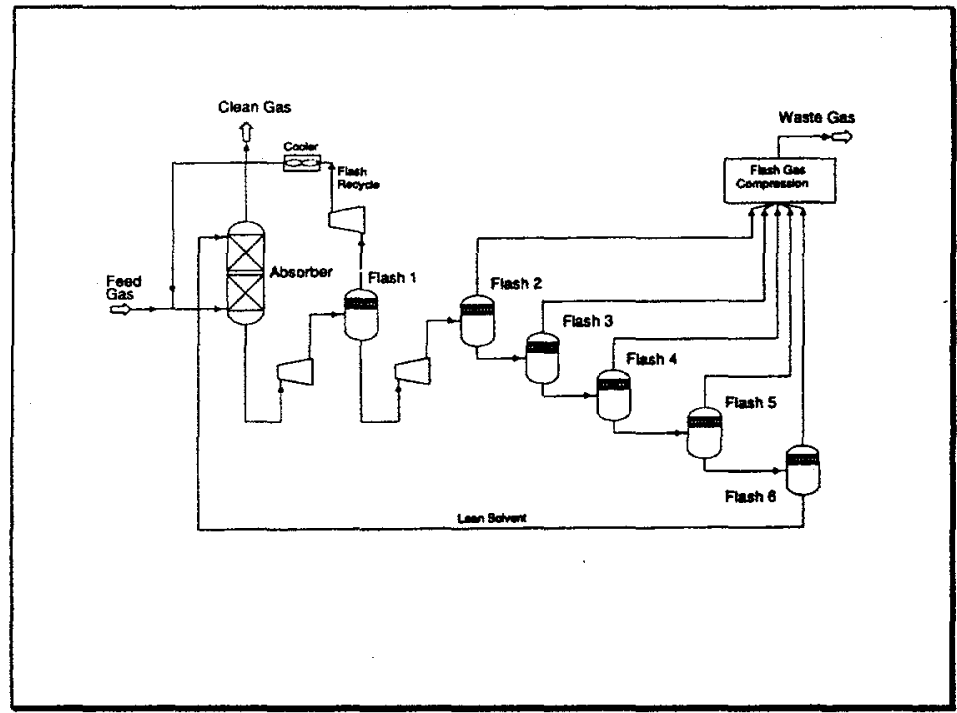

Figure 9. PARTIAL REMOVAL OF $\mathrm{H}_{2} \mathrm{~S}$ AND $\mathrm{CO}_{2}$

The equipment arrangement (Figure 9) includes the absorber with only semi-lean stage contacting, plus six flash stages at different pressures for solvent regeneration. The first flash is performed at 435 psia for recycling of the hydrocarbons containing flashed gas. The feed gas flow is $170 \mathrm{MMscfd}$ at $1200 \mathrm{psia}$ and $86^{\circ} \mathrm{F}$.

Figure 10 lists a special nature of the task and the utility figures for partial $\mathrm{CO}_{2}$ and $\mathrm{H}_{2} \mathrm{~S}$ removal. By considering this constraint the $\mathrm{H}_{2} \mathrm{~S}$ content will be reduced from $15 \%$ to $3.2 \%$ vol., while the $\mathrm{CO}_{2}$ content goes down from 10 $\%$ to $7.8 \%$ vol. Due to special requirements for treatment of the flashed acid gas, this unit is not considered in the arrangement and cost estimation as well. Taking into account the special requirements of this evaluation the specific cost can be expected of $3.25 \mathrm{cent} / \mathrm{Mscf} \mathrm{CH}_{4}$ in clean gas at a feed gas flow of $170 \mathrm{MMscfd}$. By evaluation of several process configurations it should be determined that the ratio of removed acid gas to the required operating costs result in a minimum figure. Thus, it was not requested to remove $\mathrm{CO}_{2}$ and $\mathrm{H}_{2} \mathrm{~S}$ down to a specification for further usage of the gas. 


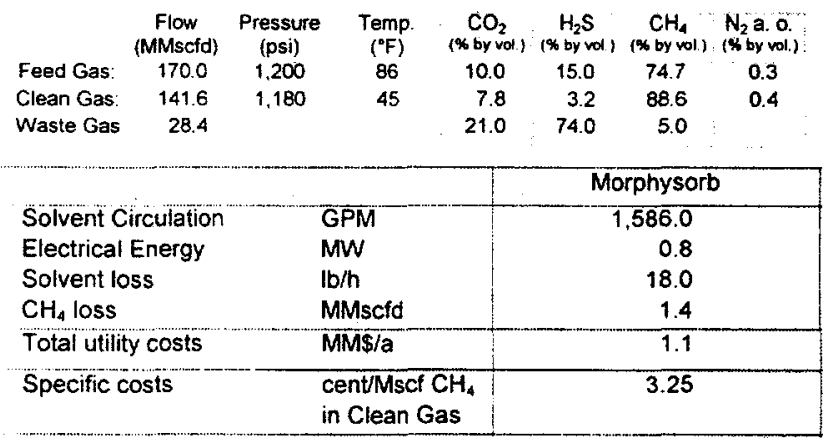

Figure 10. UTILITY COSTS - PARTIAL REMOVAL OF $\mathrm{CO}_{2} \mathrm{AND} \mathrm{H}_{2} \mathrm{~S}$

\section{CONCLUSION}

The Morphysorb solvent consisting of $\mathrm{N}$-Formylmorpholine and N-Acetylmorpholine has the same advantages as outlined for NFM, such as

- high acid gas loading,

- less loss of $\mathrm{C}_{1}-\mathrm{C}_{6}$ hydrocarbons,

- excellent removal of organic sulphur compounds,

- both chemically and thermally stable and

- Environmentally compatible.

Furthermore, this mixture of morpholines can be applied within an extended range of absorption temperatures from about $104^{\circ} \mathrm{F}$ to $14^{\circ} \mathrm{F}$, ensuring the application of the high acid gas loadings at low temperatures. This technology is presently available through Krupp Uhde for retrofit applications as well as for new plants.

\section{ACKNOWLEDGMENT}

Financial support from the Gas Research Institute, Department of Energy-Morgantown Energy Technology Center, and the Sustaining Membership Program of the Institute of Gas Technology is greatly appreciated. The authors also wish to thank the following for their support and guidance during various stages of this project, Thomas Kresse of NGPL; Jim Critchfield and Vicki Anderson of Huntsman; David Kurtz of Koch Engineering; Charles Wallace and Tom Fowler of Shell. 


\section{REFERENCES}

1. Hugman, V. and Springer, "Chemical Composition of Discovered and Undiscovered Natural Gas in the U.S. Lower-48, March 1993, Energy and Environmental Analysis, Inc.

2. Tannehill, C. C. and Gibbs, J. E., "Gas Processing Industry Lower 48 States," July 1991, Purvin \& Gertz, Inc., GRI-911/0232.

3. Macriss, R. A., and Duncan, D., "Acid-Gas and Trace Impurity Removal," Annual Report for 1975, A.G.A Project No. IU-4-10, 1976.

4. Britt, H. I. and Lueke, R. H., "The estimation of Parameters in Non-linear, Implicit Models," Technometrics, 15, 2, 283 (1973).

5. "Selexol Unit Saves Energy," Hydrocarbon Processing, April 1978.

6. Purvin \& Gertz., "Business Characteristics of the Natural Gas Industry," May 1993. 